\title{
IGFBP-rP1 acts as a potential tumor suppressor via the suppression of ERK signaling pathway in endometrial cancer cells
}

\author{
YU MA ${ }^{1}$, JUE JIANG ${ }^{2}$, YAN ZHANG $^{3}$, YI DING ${ }^{2}$, TING XU ${ }^{2}$ and BINGJIAN LU ${ }^{4}$ \\ ${ }^{1}$ Department of Clinical Laboratory, Women's Hospital, School of Medicine, Zhejiang University, Hangzhou, Zhejiang 310006; \\ ${ }^{2}$ Institute of Bioinformatics, School of Agriculture and Biological Technology, Zhejiang University, Hangzhou, \\ Zhejiang 310029; ${ }^{3}$ Department of Clinical Laboratory, Yiwu Hospital, School of Medicine, Zhejiang University, \\ Yiwu, Zhejiang 322000; ${ }^{4}$ Department of Surgical Pathology, The Affiliated Women's Hospital, \\ School of Medicine, Zhejiang University, Hangzhou, Zhejiang 310006, P.R. China
}

Received June 15, 2016; Accepted April 12, 2017

DOI: $10.3892 / \mathrm{mmr} .2017 .6713$

\begin{abstract}
Insulin-like growth factor binding protein-related protein 1 (IGFBP-rP1) is a potential tumor-suppressor gene in various cancers. However, its biological role and underlying mechanism has not been well investigated in endometrial cancer yet. The aim of the present study aimed to investigate the role and underlying molecular mechanisms of IGFBP-rP1 in endometrial cancer cells in vitro. The authors used transfection of IGFBP-rP1 or small interfering (si)RNA in endometrial cancer HEC-1A or Ishikawa cells, respectively. Biological functional alterations, such as cell growth and cell cycle were analyzed in endometrial cancer cells, combined with the use of PD98059. A panel of proteins including phospho-retinoblastoma (p-RB) and p-extracellular signal-regulated kinase $(\mathrm{ERK}) / \mathrm{ERK}$ were detected by western blot analysis. It was observed that IGFBP-rP1 transfection inhibited cell growth, and induced G1 phase arrest and cellular senescence in HEC-1A cells while gene silencing presented the adverse functional changes. Moreover, $\mathrm{p}-\mathrm{RB}$ and $\mathrm{p}-\mathrm{ERK}$ were significantly downregulated or upregulated in HEC-1A-IGFBP-rP1 cells or Ishikawa-siRNA (IGFBP-rP1) compared with control cells, respectively. These observations were reinforced in endometrial cancer cells by PD98059 treatment. The authors conclude that IGFBP-rP1 acts as a potential tumor suppressor via the suppression of the ERK signaling pathway in endometrial cancer cells. These findings suggested that IGFBP-rP1 may serve as a potential therapeutic target for cancer intervention in the future.
\end{abstract}

Correspondence to: Dr Bingjian Lu, Department of Surgical Pathology, The Affiliated Women's Hospital, School of Medicine, Zhejiang University, 1 Xueshi Road, Hangzhou, Zhejiang 310006, P.R. China

E-mail: lbj@zju.edu.cn

Key words: insulin-like growth factor binding protein-related protein 1, extracellular signal-regulated kinase, retinoblastoma protein, endometrial cancer, tumor suppressor

\section{Introduction}

The incidence of endometrial carcinoma increased steadily in the last decade (1). It has become the second most common gynecologic cancer in China (2). A substantial body of epidemiologic data indicated that metabolic syndrome, characterized by obesity, hypertension, and diabetes is closely associated with endometrial carcinoma (3). As insulin resistance is the hallmark of metabolic syndrome, more attention has been focused on the relationship between insulin-like growth factors system and endometrial carcinoma $(4,5)$.

The insulin-like growth factor binding protein (IGFBP) superfamily serves essential roles in the IGF system by modulating the bioavailability of IGFs and/or insulin (6-8). IGFBP-related protein 1 (rP1) is a secreted protein belonging to the IGFBP superfamily. IGFBP-rP1 may be associated with insulin resistance by its high affinity with insulin $(6,9)$. A previous study of the authors indicated that elevated IGFBP-rP1 was associated with decreased endometrial cancer risk (10). Insulin can promote cell growth in vitro (11). Accordingly, IGFBP-rP1 can function as a tumor-suppressor gene in various cancers including colorectal cancer and breast cancer (12-17). However, the biological role of IGFBP-rP1 in endometrial cancer has not been investigated yet. In the present study, the authors attempted to explore the role and underlying molecular mechanisms of IGFBP-rP1 in endometrial cancer cells in vitro.

\section{Materials and methods}

Materials. Human endometrial cancer cell lines Ishikawa and HEC-1A were donated by the Key Laboratory of Women's Reproductive Health of Zhejiang Province (Hangzhou, China). All cell lines were cultured in Dulbecco's modified Eagle's medium (Gibco; Thermo Fisher Scientific, Inc., Waltham, MA, USA) supplemented with $10 \%(\mathrm{v} / \mathrm{v})$ heat-inactivated bovine serum (Gibco; Thermo Fisher Scientific, Inc.) and grown at $37^{\circ} \mathrm{C}$ in an atmosphere of $95 \%$ air and $5 \% \mathrm{CO}_{2}$. The mouse anti-human IGFBP-rP1 monoclonal antibody was from R\&D Systems, Inc. (cat no. MAB1334; 1:500; Minneapolis, MN, USA). The rabbit anti-human polyclonal antibodies, $\beta$-actin (cat no. 20536-1-AP; 1:1,000), Rb (cat no. 17218-1-AP; 1:800), 
p16 (cat no. 10883-1-AP; 1:500), p21 (cat no. 10355-1-AP; 1:500), p53 (cat no. 10442-1-AP; 1:500) and extracellular signal-regulated kinase (ERK)1/2 (cat no. 16443-1-AP; 1:1,000) were from ProteinTech Group, Inc. (Chicago, IL, USA). The rabbit anti-human antibody, phospho-retinoblastoma (Thr826; p-RB; cat no. AF0030; 1:1,000) was from Affinity Biosciences (Cincinnati, OH, USA). Goat anti-human polyclonal antibody p-ERK (Tyr 204; cat no. sc-7976; 1:800) was from Santa Cruz Biotechnology, Inc. (Dallas, TX, USA). The Cell Counting Kit (CCK)-8 was from Dojindo Molecular Technologies, Inc. (Kumamoto, Japan). PD98059 was from Selleck Chemicals (Houston, TX, USA).

Cell culture, transfection and small interfering (si)RNA treatment. pcDNA 3.1 (IGFBP-rP1) containing full-length IGFBP-rP1 coding sequence was donated by Department of Pathology, School of Medicine, Zhejiang University (Hangzhou, China). DNA sequencing analysis confirmed the fidelity of the constructs. Transfection of pcDNA 3.1 (IGFBP-rP1) into HEC-1A cells, which did not express IGFBP-rP1, was performed using Lipofectamine 2000 transfection reagent (Invitrogen; Thermo Fisher Scientific, Inc.), according to the manufacturer's protocol. HEC-1A cells with an empty vector (HEC-1A-EV), produced by transducing with pcDNA 3.1/myc-His (-B) alone, was used as a negative control. Stable transfectants (HEC-1A- IGFBP-rP1) were obtained following selection with $500 \mu \mathrm{g} / \mathrm{ml} \mathrm{G} 418$ for 2 weeks.

Three different sets of siRNAs (IGFBP-rP1 siRNA) and irrelevant controls (negative control) (both from Invitrogen; Thermo Fisher Scientific, Inc.) were transiently transfected into Ishikawa cells (with IGFBP-rP1 expression) in 6-well culture dishes ( $1 \times 10^{5}$ cells) using Lipofectamine 2000 transfection reagent, according to the manufacturer's protocol. The IGFBP-rP1 siRNA\#1 targets against the exon 5 of IGFBP-rP1 (5'-CAAUCCACUAACACUUUAGUUTT-3', 5'-AACUAA AGUGUUAGUGGAUUGTT-3'), IGFBP-rP1 siRNA\#2 against the exon 2 (5'-CAGGUGUACUUGAGCUGUGAG GUCATT-3', 5'-UGACCUCACAGCUCAAGUACACCU GTT-3') and IGFBP7 siRNA\#3 against the exon 4 (5'-GCU GGAGAAUAUGAGUGCCAUGCAUTT-3', 5'-AUGCAU GGCACUCAUAUUCUCCAGCTT-3'). The Ishikawa-siRNA (IGFBP-rP1) cells were further cultured for $48 \mathrm{~h}$ until use.

Western blot analysis. Cells were separated from 6-well plates by phosphate-buffered saline (PBS) containing $0.25 \%$ trypsin-EDTA and washed 3 times with PBS, then lysed in $1 \mathrm{ml}$ lysis buffer consisting of $7 \mathrm{M}$ urea, $2 \mathrm{M}$ thiourea, 4\% CHAPS, $65 \mathrm{mM}$ DTT and 0.2\% Bio-lyte (pH 3-10; cat no. 1632094; Bio-Rad Laboratories, Inc., Hercules, CA, USA) by sonication on ice. The lysates were centrifuged at $13,500 \mathrm{x} g$ for $1 \mathrm{~h}$ at $4^{\circ} \mathrm{C}$. Subsequently, the protein concentration of the supernatants was measured by the Bradford method (Bradford Protein Assay kit, cat no. PC0010; Solarbio Science \& Technology Company, Beijing, China), and aliquots of the protein samples were stored at $-80^{\circ} \mathrm{C}$.

Aliquots of protein extracts $(50 \mu \mathrm{g})$ were separated on an $8 \%$ SDS-PAGE according to the protein molecular weight. Subsequently, the protein was electrophoretically transferred onto a polyvinylidene difluoride membrane (Bio-Rad Laboratories, Inc.). Following blocking with TBS-Tween-20
$(0.2 \%$; TBST) containing $5 \%$ non-fat milk, the membranes were incubated with primary antibodies (see above) in TBST overnight at $4{ }^{\circ} \mathrm{C}$, followed by peroxidase-conjugated second antibody [goat anti-mouse $\operatorname{IgG}(\mathrm{H}+\mathrm{L})$; cat no. 626520; 1:5,000; Thermo Fisher Scientific, Inc.; goat anti-rabbit IgG (H+L); cat no. 31460, 1:5,000; Thermo Fisher Scientific, Inc.; peroxidase-conjugated affinipure rabbit anti-goat $\operatorname{IgG}(\mathrm{H}+\mathrm{L})$; cat no. SA00001-4; 1:5,000; ProteinTech Group, Inc.] diluted in 1:5,000 in TBST for $1 \mathrm{~h}$ at room temperature. Finally, blots were developed with the Odyssey system version 3 (LI-COR Biosciences, Lincoln, NE, USA). As a control for equal protein loading, blots were re-stained using anti- $\beta$-actin antibody.

Cell proliferation assay. Cell proliferation of stable HEC-1A and Ishikawa cells was measured using the CCK-8 (Dojindo Molecular Technologies, Inc.). In brief, cells were plated in 96 -well plates at $5 \times 10^{3} /$ well. A volume of $10 \mu \mathrm{l} \mathrm{CCK-8} \mathrm{solutions}$ were added during the last $4 \mathrm{~h}$ of the culture. Optical density of the wells was measured at $450 \mathrm{~nm}$ using the Multiska FC microplate reader (Thermo Fisher Scientific, Inc.).

Flow cytometry assay. Cells were collected at $48 \mathrm{~h}$ following treatment for DNA content analysis. The adherent cells were harvested with PBS containing $0.25 \%$ trypsin-EDTA. The harvested cells were washed twice with PBS. Then the cells were treated with PBS containing $0.25 \mathrm{mg} / \mathrm{ml}$ RNase at $37^{\circ} \mathrm{C}$ for $15 \mathrm{~min}$ and incubated with $50 \mathrm{mg} / \mathrm{ml}$ propidium iodide at $4^{\circ} \mathrm{C}$ for $15 \mathrm{~min}$ in the dark. The stained cells were analyzed by flow cytometry (Beckman Coulter, Inc., Brea, CA, USA) with Cell Quest software version 6.0 (BD Biosciences, Franklin Lakes, NJ, USA).

Senescence-associated $\beta$-galactosidase (SA- $\beta$-gal) staining. The senescence status of cells was verified by in situ staining for SA- $\beta$-galactosidase, as described previously (18). Briefly, cells that were grown on $60 \mathrm{~mm}$ cell culture dishes were washed three times with PBS and fixed with $2 \%$ formaldehyde $/ 0.2 \%$ glutaraldehyde in PBS for $10 \mathrm{~min}$. Then, they were washed again and incubated with $\beta$-galactosidase substrate staining solution $[150 \mathrm{mM} \mathrm{NaCl}, 2 \mathrm{mM} \mathrm{MgCl} 2,5 \mathrm{mM}$ potassium ferricyanide, $5 \mathrm{mM}$ potassium ferrocyanide, $40 \mathrm{mM}$ citric acid and $12 \mathrm{mM}$ sodium phosphate; $\mathrm{pH}$ 6.0; containing $1 \mathrm{mg} / \mathrm{ml}$ 5-bromo-4-chloro-3-indolyl- $\beta$-d-galactoside (X-gal)] for $24 \mathrm{~h}$ at $37^{\circ} \mathrm{C}$. The cells were washed with PBS. Greenish cytoplasmic staining was regarded as positive. The positive cells were counted in three high power fields with a diameter of $4.4 \mathrm{~mm}$ (Leica DMR 2000; Leica Microsystems GmbH, Wetzlar, Germany) and recorded as a percentage of positive cells to the total. The experiment was conducted in triplicate.

Statistical analysis. Statistical analysis was performed using SPSS software (version, 19.0; IBM SPSS, Armonk, NY, USA) for Windows. The paired-sample t-test was conducted to compare protein levels and other data between groups. $\mathrm{P}<0.05$ was considered to indicate a statistically significant difference.

\section{Results}

IGFBP-rPI inhibited cell growth and induced cellular senescence in endometrial carcinoma cells. Expression of 


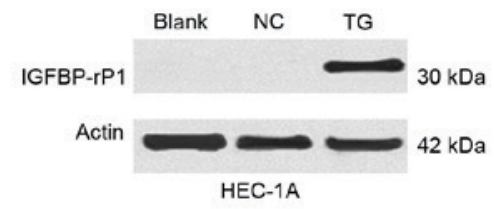

C
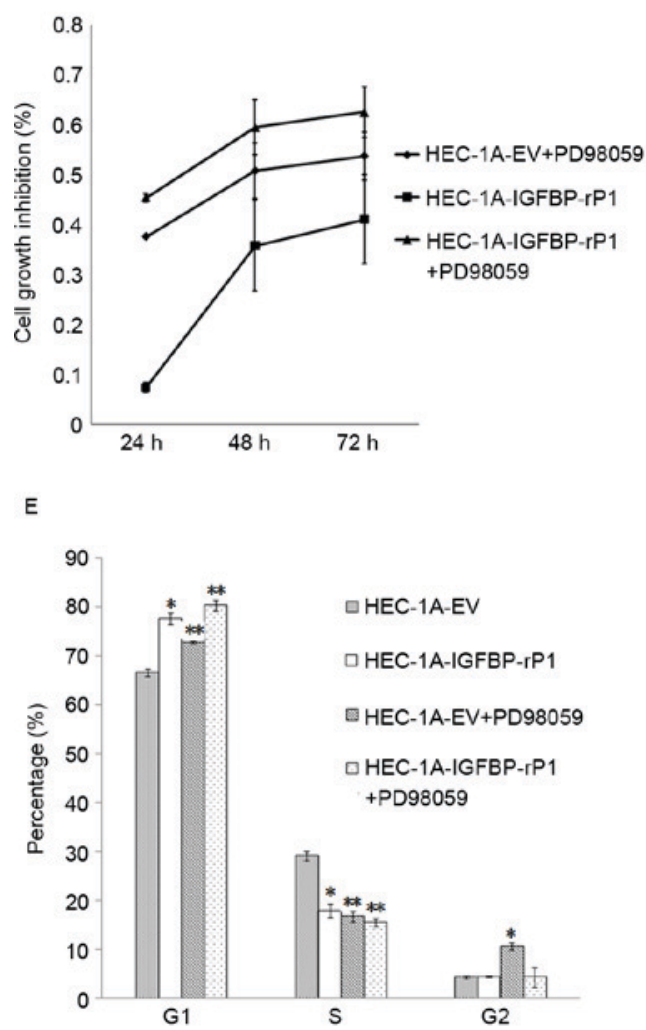

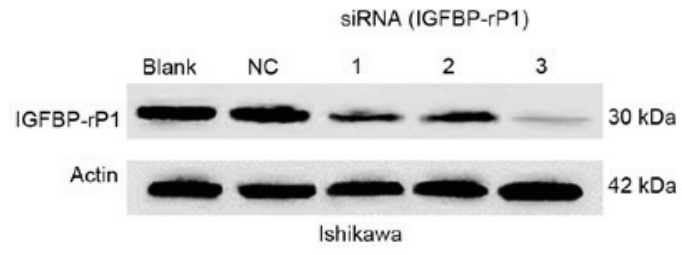

D
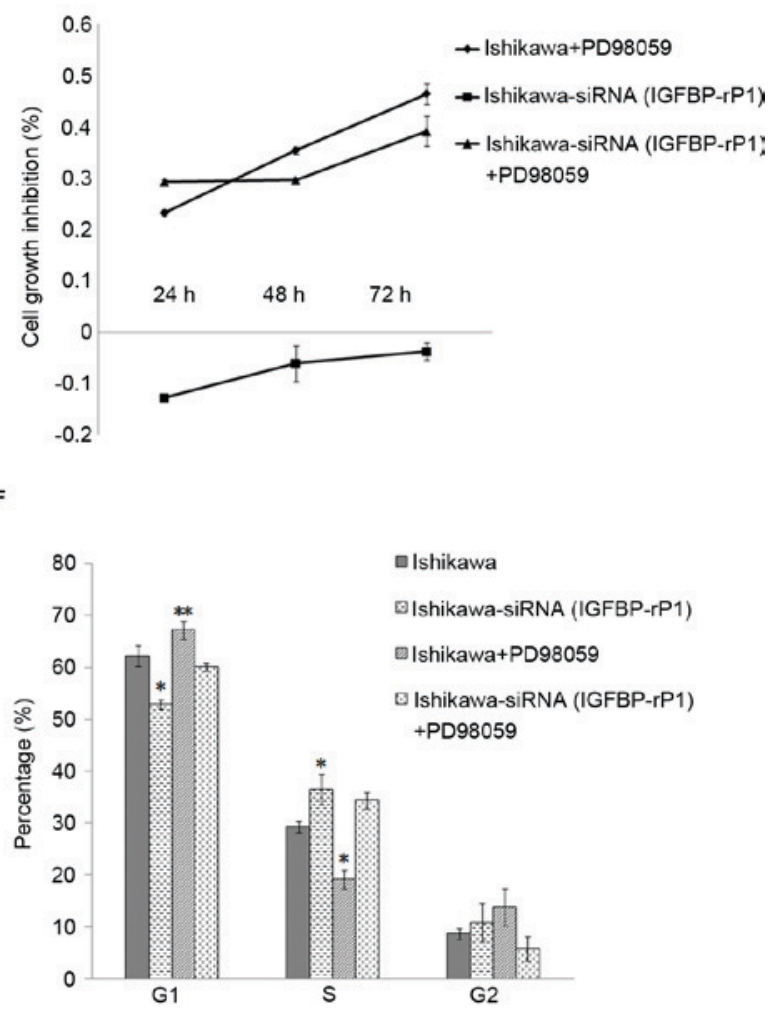

Figure 1. IGFBP-rP1 expression inhibits cell growth in HEC-1A and Ishikawa cells (A and B; Lane 1: IGFBP-rP1 siRNA\#1; Lane 2: IGFBP-rP1 siRNA\#2; Lane 3: IGFBP-rP1 siRNA\#3). Expression of IGFBP-rP1 in HEC-1A and Ishikawa endometrial cancer cells, as demonstrated by western blotting. (C and D) The effect of IGFBP-rP1 expression with/without PD98059 on the proliferation of (C) HEC-1A and (D) Ishikawa cells. Absorbance at 450 nm was detected, and ratio of cell growth inhibition as calculated as $\left(\mathrm{Ab}_{\text {control }}-\mathrm{Ab}_{\text {treatment }}\right) / \mathrm{Ab}_{\text {control }}$ ( $\mathrm{E}$ and F) Cell cycle analysis of (E) HEC-1A-IGFBP-rP1 and (F) Ishikawa-siRNA (IGFBP-rP1) cells compared with their controls. ${ }^{*} \mathrm{P}<0.05,{ }^{* *} \mathrm{P}<0.01$ vs. HEC-1A-EV. IGFBP-rP1, insulin-like growth factor binding protein-related protein 1 ; NC, negative control; TG, treatment group with transfection of pcDNA 3.1 (IGFBP-rP1); siRNA, small interferring RNA.

IGFBP-rP1 was detected by western blotting following cell transfection in HEC-1A or significantly inhibited by siRNA in Ishikawa cells (Fig. 1A and B). IGFBP-rP1 siRNA (\#3) presented the highest inhibitory effects and was used in all subsequent experiments (Fig. 1B). IGFBP-rP1 transfection suppressed the growth of HEC-1A cells compared with negative controls whereas IGFBP-rP1 silence promoted the growth of Ishikawa cells (Fig. 1C and D). IGFBP-rP1 induced cell cycle arrest by demonstrating a higher proportion of cells in the G1 phase in the HEC-1A-IGFBP-rP1 cells $(77.59 \pm 1.275 \%)$ than in the controls $(66.54 \pm 0.68 \%$; $\mathrm{P}<0.05)$ by flow cytometry with propidium iodide staining (Fig. 1E). In contrast, IGFBP-rP1 silence promoted cell cycle in Ishikawa cells as indicated by decreased cells in the G1 phase $(52.76 \pm 0.88 \%$ in IGFBP-rP1-siRNA cells vs. $62.17 \pm 1.96 \%$ in control cells, $\mathrm{P}<0.05$; Fig. $1 \mathrm{~F}$ ), and increased cells in the $\mathrm{S}$ phase
$(36.45 \pm 2.89 \%$ in IGFBP-rP1-siRNA cells vs. $29.22 \pm 0.99 \%$ in control cells; $\mathrm{P}<0.05)$.

SA- $\beta$-galactosidase staining, a golden standard for cellular senescence, indicated that HEC-1A-IGFBP-rP1 cells had a higher proportion of SA- $\beta$-galactosidase positive cells $(34.04 \pm 3.24 \%)$ than the control cells $(17.48 \pm 0.63 \%$; $\mathrm{P}<0.01$; Fig. 2A). On the contrary, SA- $\beta$-galactosidase activity significantly decreased in Ishikawa-siRNA (IGFBP-rP1) cells $(6.27 \pm 1.32 \%)$ compared with negative controls $(12.57 \pm 0.63 \%$; $\mathrm{P}<0.05$; Fig. $2 \mathrm{~B}$ and $\mathrm{C}$ ). Moreover, $\mathrm{p}-\mathrm{RB}$, a key regulator in cellular senescence, was significantly reduced in HEC-1A-IGFBP-rP1 cells than control cells $(2.64 \pm 0.21 \%$ vs. $12.95 \pm 0.31 \%$; $\mathrm{P}<0.01)$ while other senescence-related proteins, p21, p53 and p16, increased four-fold, 55-fold and 24-fold in HEC-1A-IGFBP-rP1, respectively $(\mathrm{P}<0.01$; Fig. 3A). In contrast, Ishikawa-siRNA (IGFBP-rP1) cells presented 
A

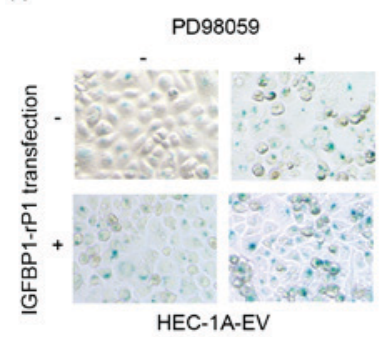

B

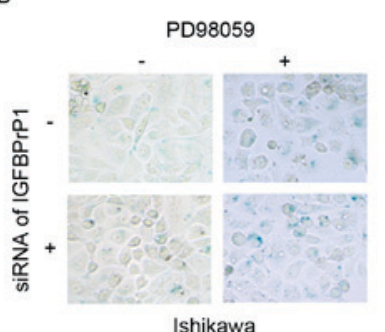

C

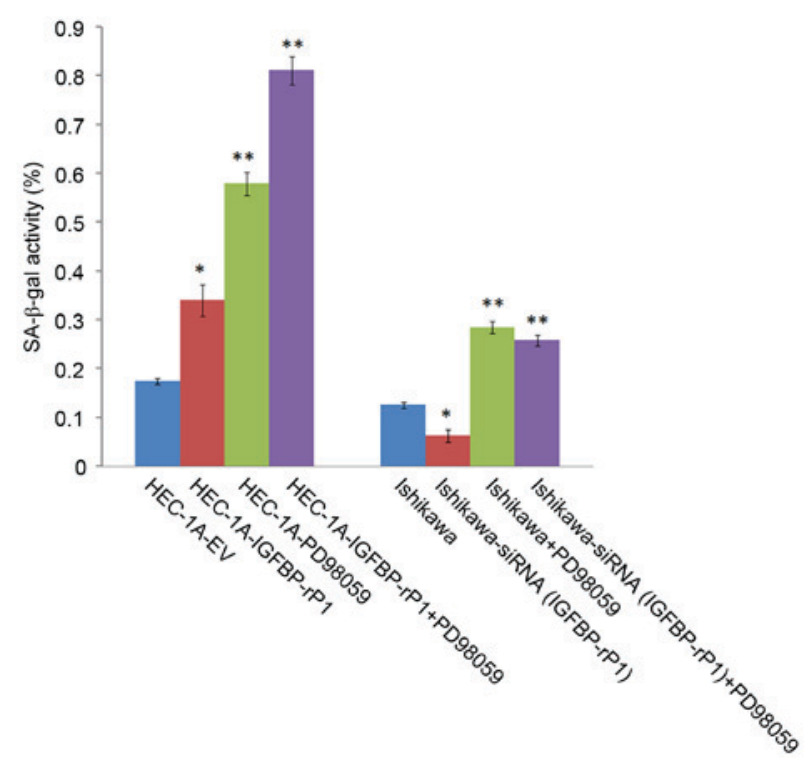

Figure 2. Alterations of SA- $\beta$-gal activity in HEC-1A-IGFBP-rP1 and Ishikawa-siRNA (IGFBP-rP1) cells. (A) SA- $\beta$-gal staining in HEC-1A-IGFBP-rP1 and its parental cells (magnification, x100) (B) SA- $\beta$-gal staining in Ishikawa-siRNA (IGFBP-rP1) and its parental cells (magnification, $x 100)$. (C) SA- $\beta$-gal activity was significantly changed between IGFBP-rP1 or IGFBP-rP1-siRNA transfectants and their controls. ${ }^{*} \mathrm{P}<0.05,{ }^{* *} \mathrm{P}<0.01$ vs. HEC-1A-EV. IGFBP-rP1, insulin-like growth factor binding protein-related protein 1 ; siRNA, small interfering RNA; SA- $\beta$-gal, SA- $\beta$-galactosidase.

a 2.8-fold increased expression of $\mathrm{p}-\mathrm{RB}(\mathrm{P}<0.01)$ and a decrease level of p16, p21 and p53 protein than control cells (p16, $1.28 \pm 0.17 \%$ vs. $9.15 \pm 0.59 \% ; \mathrm{P}<0.01 ; \mathrm{p} 53,0.27 \pm 0.05 \%$ vs. $6.11 \pm 0.48 \% ; \mathrm{P}<0.01 ; \mathrm{p} 21,6.09 \pm 0.31 \%$ vs. $8.88 \pm 0.56 \%$; $\mathrm{P}<0.05$; Fig. $3 \mathrm{~B}$ ). The levels of total $\mathrm{RB}$ protein demonstrated no significant changes between transfectants and control cells.

The suppression of $p$-ERK/ERK pathway is associated with the biological functions of IGFBP-rPI. To explore the underlying cell growth inhibition mechanisms of IGFBP-rP1, the authors analyzed the activities of the ERK pathway in endometrial cells with forced or deprived IGFBP-rP1 expression. A 97.5\% reduction of $\mathrm{p}$-ERK was present in HEC-1A-IGFBP-rP1 cells vs. control cells $(\mathrm{P}<0.01)$ and a 3.21 -fold increase in Ishikawa-siRNA (IGFBP-rP1) cells vs. control cells $(\mathrm{P}<0.01$; Fig. 3). The total ERK protein levels remained stable between transfectants and control cells.

PD98059, an inhibitor of the MAP/ERK kinase (MEK)/ERK pathway, significantly suppressed cell proliferation and induced cellular senescence in endometrial cancer cells (Figs. 1C and D and 2A and B). Moreover,

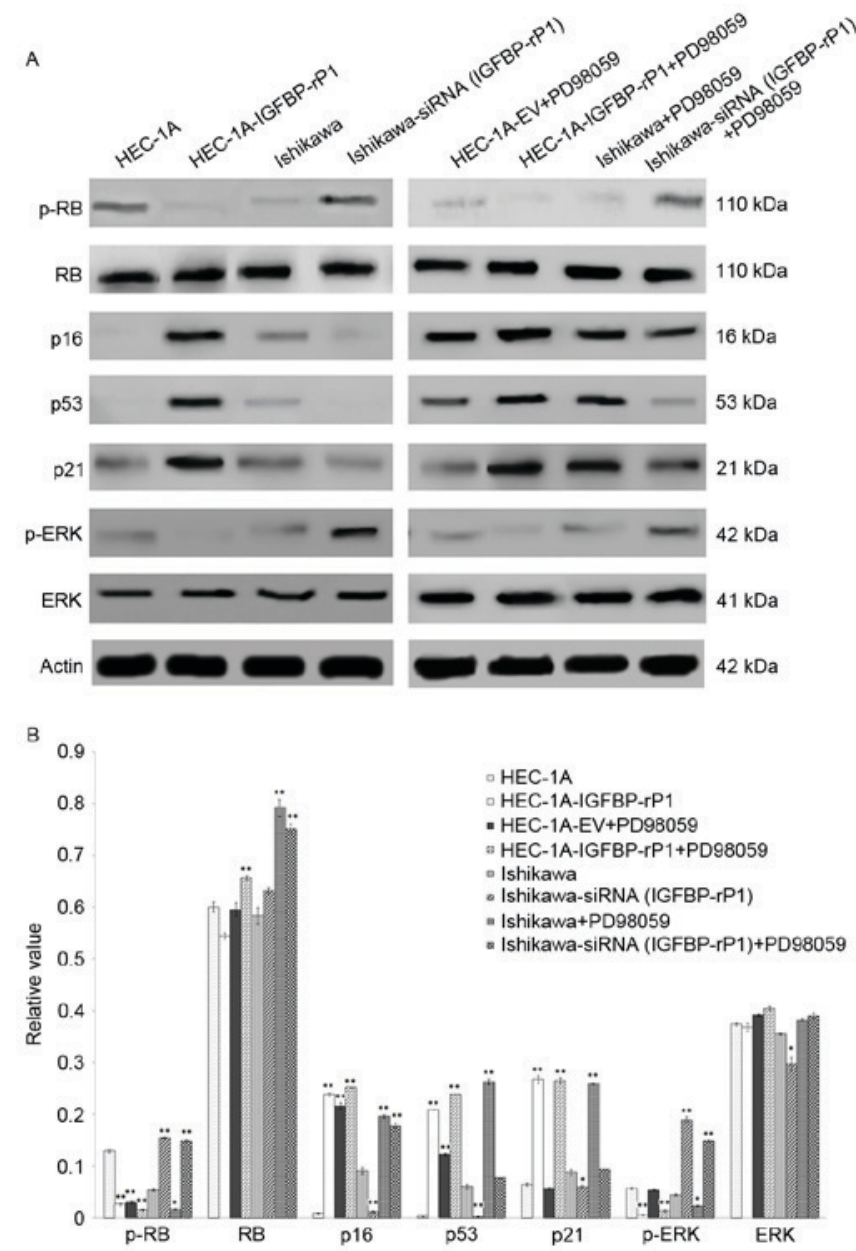

Figure 3. Differential expression patterns of p-RB, p16, p53, p21 and p-ERK in endometrial cancer cells. (A) Western blotting images of related proteins. (B) Statistical analysis of these proteins between IGFBP-rP1 knock-in or knock-out cells with/without PD98059 compared with controls. ${ }^{*} \mathrm{P}<0.05$, ${ }^{* *} \mathrm{P}<0.01$ vs. controls (HEC-1A/Ishikawa). RB, retinoblastoma; ERK, extracellular signal-regulated kinase; siRNA, small interfering RNA; IGFBP-rP1, insulin-like growth factor binding protein-related protein 1.

HEC-1A-IGFBP-rP1 cells with PD98059 treatment reported an additive effect on cell growth inhibition compared to control cells with PD98059 treatment alone or HEC-1A-IGF BP-rP1 (Fig. 1C and D). G1 phase arrest was more apparent in HEC-1A-IGFBP-rP1 cells with PD98059 treatment compared to control cells with PD98059 treatment or IGFBP-rP1 transfection alone (cells in G1 phase: PD98059+IGFBP-rP1, $80.27 \pm 1.165 \%$ vs. PD98059, $72.76 \pm 0.35 \%$ or IGFBP-rP1, $77.59 \pm 1.275 \%$; $\mathrm{P}<0.01$; cells in S phase: PD98059+IGFBP-rP1, $15.45 \pm 0.86 \%$ vs. PD98059, $16.68 \pm 1.06 \%$ or IGFBP-rP1, $17.93 \pm 1.41 \% ; \mathrm{P}<0.05 ;$ Fig. 1E). In Ishikawa cells, IGFBP-rP1-siRNA alleviated G1 phase arrest of PD98059 treatment (cells in G1 phase: IGFBP-rP1-siRNA+PD98059, $60.02 \pm 0.84 \%$ vs. PD98059, 67.12 $\pm 1.70 \%$; P<0.01; Fig. 1F).

HEC-1A-IGFBP-rP1 cells with PD98059 presented more SA- $\beta$-galactosidase positive cells than HEC-1A with PD98059 treatment $(81.11 \pm 2.94 \%$ vs. $57.89 \pm 2.44 \%$; $\mathrm{P}<0.01)$ or HEC-1A-IGFBP-rP1 cells $(81.11 \pm 2.94 \%$ vs. $34.04 \pm 3.24 \%$; $\mathrm{P}<0.01$; Fig. 2 C). SA- $\beta$-galactosidase activity significantly decreased in Ishikawa-siRNA (IGFBP-rP1) cells with PD98059 compared with controls (PD98059 alone, $25.80 \pm 1.15 \%$ vs. 
$28.48 \pm 1.16 \%$; $\mathrm{P}<0.05)$. PD98059 can significantly downregulate $\mathrm{p}-\mathrm{RB}$ expression, and upregulate the expression of p16 and p53 in both HEC-1A and Ishikawa cells ( $\mathrm{P}<0.01$; Fig. 3), but did not influence the level of total RB protein in endometrial cancer cells. PD98059 presented a lower level of p-RB and p-ERK (p-RB, $1.62 \pm 0.12 \%$ vs. $3.08 \pm 0.29 \%$; P<0.01; p-ERK, $1.44 \pm 0.24 \%$ vs. $5.39 \pm 0.11 \%$; $\mathrm{P}<0.01$ ), and upregulated expression of the p16, p53 and p21 proteins in HEC-1A-IGFBP-rP1 cells than in control HEC-1A cells (p16, 25.20 $0.09 \%$ vs. $21.62 \pm 0.67 \%$; $\mathrm{P}<0.05 ; \mathrm{p} 53,23.96 \pm 0.01 \%$ vs. $12.31 \pm 0.23 \%$; $\mathrm{P}<0.05$; $21,26.55 \pm 0.59 \%$ vs. $5.70 \pm 0.28 \%$; $\mathrm{P}<0.01)$. On the contrary, PD98059 significantly upregulated the expression of p-RB and p-ERK (p-RB, 14.90 $\pm 0.21 \%$ vs. $1.75 \pm 0.08 \%$; $\mathrm{P}<0.01$; p-ERK, $14.89 \pm 0.16 \%$ vs. $2.39 \pm 0.09 \%$; $\mathrm{P}<0.01)$, and significantly downregulated the expressions of p16, p53 and p21 in Ishikawa-siRNA (IGFBP-rP1) cells than in control Ishikawa cells (p16, 17.77 $\pm 0.46 \%$ vs. $19.71 \pm 0.31 \%$; $\mathrm{P}<0.05$; p53, 7.76 $\pm 0.11 \%$ vs. $26.34 \pm 0.54 \%$; $\mathrm{P}<0.01$; p21, $9.42 \pm 0.09 \%$ vs. $25.98 \pm 0.12 \% ; \mathrm{P}<0.01)$.

\section{Discussion}

Accumulative evidence indicates that metabolic syndrome is closely associated with endometrial carcinoma $(3,19,20)$. Insulin resistance remains the pillar of metabolic syndrome. The dysfunction of the insulin/IGF/IGFBP axis serves essential roles in insulin resistance. Numerous research has been focused on the role of the insulin/IGF/IGFBPs axis in metabolic syndrome and related diseases including endometrial carcinoma (4-8). IGFBP-rP1 is a secreted factor belonging to the IGFBP family. IGFBP-rP1 may play a tumor-suppressor role in various tumors (12-17), but its biological functions in endometrial carcinoma have not been fully investigated yet. In the present study, the authors found that IGFBP-rP1 can inhibit cell proliferation and induce cell senescence in endometrial cancer cell lines. These findings supported the idea that IGFBP-rP1 functioned as a tumor suppressor in endometrial carcinoma.

IGFBP-rP1, also known as MAC25 or IGFBP7, was initially isolated from the senescent breast cancer cells (21). A number of studies validated the role of IGFBP-rP1 in cellular senescence in various carcinomas $(13-15,17,22)$. The $\mathrm{p}-\mathrm{RB} / \mathrm{p} 53$ pathway is well known to be the classical pathway in the process of cellular senescence (23-26). In the current study, IGFBP-rP1-transfection was shown to downregulate the expression of $\mathrm{p}-\mathrm{RB}$ and upregulate the expression of p53, p16 and p21 in endometrial carcinoma cells, while IGFBP-rP1 silence demonstrated the opposite roles. These results clearly demonstrated that IGFBP-rP1 can activate key factors, such as p-RB, p53 and p21, in the p-RB/p53 pathway to trigger cellular senescence in endometrial carcinoma. These results are in-keeping with several reports from other cancers $(13-15,17,22)$. Wajapeyee et al (22) reported that IGFBP7, had a central role in BRAFV600E-mediated senescence and apoptosis in melanoma cells. Early work of the authors indicated that IGFBP-rP1 could promote cellular senescence in colorectal cancer cells (17).

IGFBP-rP1 binds to IGF-1 and IGF-2 with 100-fold lower affinity than IGFBP1 to IGFBP6, which infers that IGFBP-rP1 may act in both an IGF-dependent and an IGF-independent way (9). The IGF-dependent route is well established as the central role in insulin resistance by the activation of the $\mathrm{PI} 3 \mathrm{~K} / \mathrm{AKT}$ signaling pathway. In contrast, the IGF-independent manner of IGFBP-rP1 remains largely unknown at present. ERK is generally considered to be anti-apoptotic, and ERK signaling pathway is essential to cellular growth and survival. Sustained activation of ERK1/ERK2 is necessary for G1- to S-phase progression and is associated with induction of positive regulators of the cell cycle and inactivation of anti-proliferative genes (27). In the present study, the authors' results clearly demonstrate that IGFBP-rP1 functions through inhibition of the ERK signaling pathway. IGFBP-rP1 could downregulate the $\mathrm{p}-\mathrm{ERK}$ protein. The combination of IGFBP-rP1 and PD98059, an inhibitor of the MEK/ERK pathway, had synergistic effects on cell proliferation suppression and cellular senescence in endometrial cancer cells. Moreover, IGFBP-rP1-siRNA alleviated cell growth inhibition and cellular senescence, which were caused by the blockage of ERK signaling pathway by PD98059 in endometrial cancer cells. A previous study in breast cancer cells also indicated that IGFBP-7 (IGFBP-rP1) strongly suppressed the phosphorylation of ERK1/2, suggesting that IGFBP-7 mediates its anti-proliferative effects through negative feedback signaling (28). In addition, Wajapeyee et al (22) indicated that IGFBP7 induced senescence and apoptosis through autocrine/paracrine pathways to inhibit BRAF-MEK-ERK signaling in BRAFV600E-expressing melanoma cells.

In summary, the present study demonstrated that IGFBP-rP1 acts as a potential tumor suppressor via the suppression of the ERK signaling pathway in endometrial cancer cells. These findings suggested that IGFBP-rP1 may be a potential therapeutic target for cancer intervention. However, further investigation is required to clarify the detailing of the IGFBP-rP1 and ERK networks and their roles in vivo.

\section{Acknowledgments}

The present work was supported by grants from the National Natural Science Foundations of China (grant nos. 81202067 and 81372790) and the Zhejiang Provincial Natural Science Foundation of China (grant no. LQ12H16008).

\section{References}

1. Kitson SJ, Evans DG and Crosbie EJ: Identifying high-risk women for endometrial cancer prevention strategies: Proposal of an endometrial cancer risk prediction model. Cancer Prev Res (Phila) 10: 1-13, 2017.

2. Wei KR, Chen WQ, Zhang SW, Zheng RS, Wang YN and Liang $\mathrm{ZH}$ : Epidemiology of uterine corpus cancer in some cancer registering areas of China from 2003-2007. Zhonghua Fu Chan Ke Za Zhi 47: 445-451, 2012 (In Chinese).

3. Esposito K, Chiodini P, Capuano A, Bellastella G, Maiorino MI and Giugliano D: Metabolic syndrome and endometrial cancer: A meta-analysis. Endocrine 45: 28-36, 2014.

4. Bruchim I, Sarfstein R and Werner H: The IGF hormonal network in endometrial cancer: Functions, regulation, and targeting approaches. Front Endocrinol (Lausanne) 5: 76, 2014.

5. McGrath M, Lee IM, Buring J and De Vivo I: Common genetic variation within IGFI, IGFII, IGFBP-1, and IGFBP-3 and endometrial cancer risk. Gynecol Oncol 120: 174-178, 2011.

6. Yamanaka Y, Wilson EM, Rosenfeld RG and Oh Y: Inhibition of insulin receptor activation by insulin-like growth factor binding proteins. J Biol Chem 272: 30729-30734, 1997.

7. Ricort JM: Insulin-like growth factor binding protein (IGFBP) signalling. Growth Horm IGF Res 14: 277-286, 2004. 
8. Hwa V, Oh Y and Rosenfeld RG: The insulin-like growth factor-binding protein (IGFBP) superfamily. Endocr Rev 20: 761-787, 1999.

9. Oh Y, Nagalla SR, Yamanaka Y, Kim HS, Wilson E and Rosenfeld RG: Synthesis and characterization of insulin-like growth factor-binding protein (IGFBP)-7. Recombinant human mac25 protein specifically binds IGF-I and -II. J Biol Chem 271: 30322-30325, 1996.

10. Zhan Y, Wang J, Ma Y, Liu Z, Xu H, Lu S and Lu B: Serum insulin-like, growth factor binding protein-related protein 1 (IGFBP-rP1) and endometrial cancer risk in Chinese women. Int J Cancer 132: 411-416, 2013.

11. Serafim MK, Silva GM, Duarte AB, Araújo VR, Silva TF, Lima AK, Chaves RN, Campello CC, Silva LD and Figueiredo JR: High insulin concentrations promote the in vitro growth and viability of canine preantral follicles. Reprod Fertil Dev 25: 927-934, 2013.

12. Chen Y, Pacyna-Gengelbach M, Ye F, Knösel T, Lund P, Deutschmann N, Schlüns K, Kotb WF, Sers C, Yasumoto H, et al: Insulin-like growth factor binding protein-related protein 1 (IGFBP-rP1) has potential tumour-suppressive activity in human lung cancer. J Pathol 211: 431-438, 2007.

13. Vizioli MG, Sensi M, Miranda C, Cleris L, Formelli F, Anania MC, Pierotti MA and Greco A: IGFBP7: An oncosuppressor gene in thyroid carcinogenesis. Oncogene 29: 3835-3844, 2010.

14. Benatar T, Yang W, Amemiya Y, Evdokimova V, Kahn H, Holloway $\mathrm{C}$ and Seth A: IGFBP7 reduces breast tumor growth by induction of senescence and apoptosis pathways. Breast Cancer Res Treat 133: 563-573, 2012.

15. Chen D, Yoo BK, Santhekadur PK, Gredler R, Bhutia SK, Das SK, Fuller C, Su ZZ, Fisher PB and Sarkar D: Insulin-like growth factor-binding protein-7 functions as a potential tumor suppressor in hepatocellular carcinoma. Clin Cancer Res 17: 6693-6701, 2011

16. Verhagen HJ, de Leeuw DC, Roemer MG, Denkers F, Pouwels W, Rutten A, Celie PH, Ossenkoppele GJ, Schuurhuis GJ and Smit L: IGFBP7 induces apoptosis of acute myeloid leukemia cells and synergizes with chemotherapy in suppression of leukemia cell survival. Cell Death Dis 5: e1300, 2014.

17. Ma Y, Lu B, Ruan W, Wang H, Lin J, Hu H, Deng H, Huang Q and Lai M: Tumor suppressor gene insulin-like growth factor binding protein-related protein 1 (IGFBP-rP1) induces senescence-like growth arrest in colorectal cancer cells. Exp Mol Pathol 85: $141-145,2008$
18. Dimri GP, Lee X, Basile G, Acosta M, Scott G, Roskelley C, Medrano EE, Linskens M, Rubelj I, Pereira-Smith O, et al: A biomarker that identifies senescent human cells in culture and in aging skin in vivo. Proc Natl Acad Sci USA 92: 9363-9367, 1995.

19. Rosato V, Zucchetto A, Bosetti C, Dal Maso L, Montella M, Pelucchi C, Negri E, Franceschi S and La Vecchia C: Metabolic syndrome and endometrial cancer risk. Ann Oncol 22: 884-889, 2011.

20. Ni J, Zhu T, Zhao L, Che F, Chen Y, Shou H and Yu A: Metabolic syndrome is an independent prognostic factor for endometrial adenocarcinoma. Clin Transl Oncol 17: 835-839, 2015.

21. Swisshelm K, Ryan K, Tsuchiya K and Sager R: Enhanced expression of an insulin growth factor-like binding protein (mac25) in senescent human mammary epithelial cells and induced expression with retinoic acid. Proc Natl Acad Sci USA 92: 4472-4476, 1995.

22. Wajapeyee N, Serra RW, Zhu X, Mahalingam M and Green MR: Oncogenic BRAF induces senescence and apoptosis through pathways mediated by the secreted protein IGFBP7. Cell 132: 363-374, 2008.

23. Xue W, Zender L, Miething C, Dickins RA, Hernando E, Krizhanovsky V, Cordon-Cardo C and Lowe SW: Senescence and tumour clearance is triggered by p53 restoration in murine liver carcinomas. Nature 445: 656-660, 2007.

24. Dimova DK and Dyson NJ: The E2F transcriptional network: Old acquaintances with new faces. Oncogene 24: 2810-2826, 2005.

25. Rowland $\mathrm{BD}$ and Bernards R: Re-evaluating cell-cycle regulation by E2Fs. Cell 127: 871-874, 2006

26. Gil J and Peters G: Regulation of the INK4b-ARF-INK4a tumour suppressor locus: All for one or one for all. Nat Rev Mol Cell Biol 7: 667-677, 2006.

27. Meloche S and Pouysségur J: The ERK1/2 mitogen-activated protein kinase pathway as a master regulator of the G1- to S-phase transition. Oncogene 26: 3227-3239, 2007.

28. Amemiya Y, Yang W, Benatar T, Nofech-Mozes S, Yee A, Kahn H, Holloway C and Seth A: Insulin like growth factor binding protein-7 reduces growth of human breast cancer cells and xenografted tumors. Breast Cancer Res Treat 126: 373-384, 2011. 